\title{
Original
}

\author{
J.Soc.Cosmet.Chem.Jpn. \\ 45 (2) $100 \stackrel{\text { Original }}{-} 107$ (2011)
}

\section{A Novel Method Using a Keratin Film for Quantifying the Photo-Modification of Hair Proteins *}

\author{
Tomoyuki Kawasoe **, Tomoko Watanabe **, Toshihiro Fujii *** \\ Shiseido Co., Ltd Research Center ${ }^{* *}$, \\ Faculty of Textile Science and Technology, Shinshu University ***
}

\begin{abstract}
We have developed a method to detect UV-dependent formation of carbonylated proteins in human hair using fluorescein-5-thiosemicarbazide (5-FTSC) and fluorescent microscopy. In this study, hair keratin films consisting of $\alpha$-keratin and keratin-associated proteins (KAPs) were prepared and utilized as a substitute device for a hair sample. When the fluorescence intensity was observed in the hair keratin films after irradiation with UV rays, the formation of carbonylated proteins in the hair keratin film prepared by the pre-cast method was higher than that of keratin films prepared by other methods. The fluorescent intensity was increased in proportion to the irradiation time with a high coefficient of correlation $\left(R^{2}=0.97\right)$ and this became evident within $10 \mathrm{~min}$ of irradiating the film. The sensitivity of 5-FTSC in the keratin film was approximately 6-fold higher compared with that of hair samples. The keratin film was sensitive to both UVA and UVB exposures. Immunoblot analysis also showed that the increase of oxidative proteins from the keratin films was observed in the film irradiated over $120 \mathrm{~min}$. The sensitivity, however, was low compared with the fluorescent microscopic observation. Fourier-transform infrared measurement showed that the formation of cysteic acid was detected in the film irradiated for $240 \mathrm{~min}$, though that of carbonyl compounds was not.
\end{abstract}

Key words : keratin film, carbonylated protein, hair, photo-modification, fluorescein-5-thiosemicarbazide (5-FTSC), UVA, UVB, pre-cast method, immunoblot analysis, cysteic acid

\section{Introduction}

When human hair is exposed to sunlight unconsciously, several kinds of damage occur and are accumulated in the hair structure. UV rays as well as chemical treatments can lead to various kinds of damage of human hair, such as degradation of hair cuticle ${ }^{1)-3)}$, decrease of tensile strength $^{4)}$, changes in hair color ${ }^{4), 5)}$, decrease of water content ${ }^{6}$, and changes in amino acid composition ${ }^{7)}$ and lipid composition ${ }^{8}$. Hair is a biomaterial suitable for research, because it can be collected easily and undergoes little alternation after a long-term storage. The measurement of tensile strength along the hair axis is the predominant method which has been used for the quantification of the hair damage caused by chemical treatments and prolonged UV irradiation ${ }^{4), 5)}$. However, this method is not fitting for detecting minor damage caused by daily sunlight exposure, since tensile strength does not reflect such damage immediately.

Recently, we have developed a practical method to detect carbonylated proteins of human hair caused by artificial sunlight exposure using fluorescein-5-thiosemicarbazide (5-FTSC) ${ }^{9)}$. The collection of a large quantity of hair from one person is difficult and each section of hair (root to tip) has a different history of damages. Thus, the data is susceptible to wide variation, even when the hair samples originate from the same person.

\footnotetext{
* Received September 3, 2010 ; Accepted January 28, 2011

** 2-2-1, Hayabuchi, Tsuzuki-ku, Yokohama 224-8558, Japan

*** 3-15-1, Tokida, Ueda 386-8567, Japan
} 
Convenient preparation procedures of the keratin film have been reported using hair protein solution solubilized by the Shindai method ${ }^{10)}$. Scanning electron microscopic observation showed that the surface of the keratin films was composed of particles, filaments, and porous structures, and the fine constitution of it was dependent on the preparation procedure used ${ }^{11)}$. Although the mechanical strength of the keratin films was fairly low, the keratin films attached on culture dishes could apparently resist chemical treatments. To quantify photo-modification with high sensitivity, the availability of the keratin film instead of hair samples can be summarized as follows. (1) The keratin film is predominantly composed of $\alpha$-keratin and keratin-associated proteins (KAPs) that were carbonylated on hair after irradiation in our previous study ${ }^{9)}$. (2) The appropriate film for the detection of photochemical alternation can be selected among various types of the keratin films. (3) The films with the same characteristics can be mass-produced.

In the present study, we applied human hair keratin films to establish a novel method for the detection of photomodification by artificial sunlight exposure at early stage.

\section{Materials and Methods}

\subsection{Preparation of human hair protein solution and keratin film}

All hair samples were collected from many male Japanese volunteers with non-damaged black hair and were used for these experiments. After washing, the hair samples were mixed with Shindai solution using 2-mercaptoethanol (2-ME) containing $25 \mathrm{mM}$ Tris- $\mathrm{HCl}(\mathrm{pH} 8.5), 2.6 \mathrm{M}$ thiourea, $5 \mathrm{M}$ urea and $250 \mathrm{mM}$ 2-ME and incubated for 3 days at $50^{\circ} \mathrm{C}$, or with Shindai solution using dithiothreitol (DTT) containing $25 \mathrm{mM}$ Tris- $\mathrm{HCl}(\mathrm{pH} 8.5), 5 \mathrm{M}$ urea, $2.6 \mathrm{M}$ thiourea, and $250 \mathrm{mM}$ DTT respectively, and were incubated for $24 \mathrm{~h}$ at $50^{\circ} \mathrm{C}{ }^{10}$. The mixtures were filtered and used as hair protein solution. The protein amount was determined by the colorimetric method of Bradford using the Bio-Rad protein assay kit (Bio-Rad) ${ }^{12}$.

Pre-cast method ${ }^{11}$ : The protein solutions $(40-60 \mathrm{mg} / \mathrm{ml})$ dissolved in Shindai solution containing 2-ME or DTT were mixed with acetic acid (final concentrations: 0-30\%) and the mixtures $(0.7 \mathrm{ml}$ ) were quickly poured onto culture dishes (Falcon) containing $5 \mathrm{ml}$ of distilled water. After letting them stand for $1-2 \mathrm{~h}$ at room temperature, the resulting protein aggregates were washed by flowing water over $12 \mathrm{~h}$ and then placed in distilled water for $3 \mathrm{~h}$.

Post-cast method ${ }^{11)}$ (forward method): The protein solutions $(0.5 \mathrm{ml})$ were directly exposed in culture dishes containing $5 \mathrm{ml}$ of $100 \mathrm{mM}$ acetic buffer solution ( $\mathrm{pH} \mathrm{4.0)}$ and the formed protein aggregates were washed as mentioned above.

Post-cast method (reverse method): The solution of $100 \mathrm{mM}$ acetic buffer solution ( $\mathrm{pH}$ 4.0) was poured into culture dishes containing $0.5 \mathrm{ml}$ of the protein solution and the formed protein aggregates were washed as mentioned above.

These keratin films were completely dried in a silica gel box and the protein recovery of the film was calculated by weighing it.

\subsection{Artificial sunlight irradiation and image analysis}

Before use, the keratin films were washed with distilled water and dried completely again. Then, the keratin films were divided into non-irradiation and irradiation areas by a piece of aluminum foil at the center. The irradiation of the keratin films was performed by $1000 \mathrm{~W}$ type solar simulator (ORIEL, Stratford, CA, USA) at $55 \mathrm{~J} / \mathrm{cm}^{2}$ for various lengths of time $(10,30,60,120,240 \mathrm{~min})$. This UV dose $(60 \mathrm{~min})$ was almost the same as the irradiation for 180 min at high noon (10: 30 to 13: 30) in the midsummer in Yokohama, Japan.

After the irradiation, the keratin films in culture dishes were mixed with a staining solution containing $20 \mu \mathrm{M}$ 5-FTSC in $100 \mathrm{mM}$ 2-morpholinoethane sulfonic acid (MES) $\mathrm{NaOH}$ ( $\mathrm{pH}$ 5.5) for $15 \mathrm{~min}$ at room temperature. To remove non-reacting 5-FTSC, the films were washed with $10 \mathrm{X} \mathrm{SCC}(0.1 \% \mathrm{SDS}, 300 \mathrm{mM} \mathrm{NaCl}$, and $30 \mathrm{mM}$ sodium citrate buffer $(\mathrm{pH} \mathrm{7.0)})$, then $1 \mathrm{X} \mathrm{SSC}(0.1 \% \mathrm{SDS}, 30 \mathrm{mM} \mathrm{NaCl}$, and $3 \mathrm{mM}$ sodium citrate buffer ( $\mathrm{pH} 7.0)$ ), and finally in distilled water sequentially. After washing, the films were dried at room temperature. All procedures were carried out in a dark room. The keratin films were observed by a fluorescence microscopy (Keyence VB-G25, Keyence, Osaka, Japan) and fluorescent images were taken at forty different points on each area. The average fluorescence intensity was calculated by image analysis. For the improvement of quantification, the fluorescence intensity was also measured by microplate fluorometer (Fluoroskan Ascent FL, Labsystem, Helsinki, Finland).

\subsection{Effect of the different spectral regions}

To assess the influence of UVA, UVB, and visible light (VIS) on the formation of carbonylated proteins, the keratin films were exposed to artificial sunlight with two different optical filters. Two colorless optical filters were used for cut-offs in the UVB range at wavelengths below $320 \mathrm{~nm}$ (WG335, Schott, Clichy, France) and in the UVA and 
UVB range at wavelengths below $400 \mathrm{~nm}$ (FUJIFILM SC-42, Tokyo, Japan).The irradiation dose was measured by a UV-Grating Spectroradiometer MS-701 (EKO Instruments Corporation, Tokyo, Japan). By a combination of the optical filters, irradiation could be performed selectively with three conditions of UVA + VIS and VIS, as well as $\mathrm{UVA}+\mathrm{UVB}+\mathrm{VIS}$.

\subsection{Electrophoresis and immunoblot analysis}

Proteins contained in the films were re-extracted using Shindai solution containing $25 \mathrm{mM}$ Tris- $\mathrm{HCl}(\mathrm{pH} 8.5), 5$ $\mathrm{M}$ urea, 2.6 M thiourea, and $250 \mathrm{mM}$ DTT and incubated for $24 \mathrm{~h}$ at $50^{\circ} \mathrm{C}$. The protein solutions were centrifuged at $12000 \mathrm{~g}$ for $10 \mathrm{~min}$ at $25^{\circ} \mathrm{C}$ and the supernatant was used for the experiments.

The hair protein solution was diluted with distilled water at $0.6 \mathrm{mg} / \mathrm{ml}$ and the compositions were analyzed by SDS-PAGE ${ }^{13)}$ using 5-20\% polyacrylamide gradient gels. Proteins were electrophoretically transferred to nitrocellulose membranes and stained with amide black solution. The membranes were thoroughly washed with PBS and then were reacted with dinitrophenyl (DNP) hydrazone for $15 \mathrm{~min}$ at $25^{\circ} \mathrm{C}$ (OxyBlot ${ }^{\mathrm{TM}}$ Protein Oxidation Detection Kit, Chemicon, USA \& Canada). After blocking the membranes with the reagent N-102 (NOF Corporation, Tokyo, Japan), they were incubated with $1 / 150$ anti-DNP antibody for $60 \mathrm{~min}$ at $25^{\circ} \mathrm{C}$. Following a wash with PBS containing $0.1 \%$ Tween 20 , the membranes were reacted with $1 / 300$ peroxidase-conjugated anti-rabbit IgG for $1 \mathrm{~h}$ at $25^{\circ} \mathrm{C}$. Then, the membranes were washed with PBS containing $0.1 \%$ Tween 20, and the immunoreactive bands were developed using Super Signal West Trial Kit (Thermo, Rockford, IL, USA).

\subsection{Fourier-transform infrared spectrum}

The powder samples were prepared from the keratin films irradiated for 0, 60, and $240 \mathrm{~min}$. Fourier-transform infrared (FT-IR) measurement was done by the attenuated total reflection method (ATR method) using a IR Prestige-21 (Shimadzu, Odawara, Japan). The intensities of the infrared absorption bands for the cysteic acid $\left(\mathrm{RSO}_{3} \mathrm{H}: 1041 \mathrm{~cm}^{-1}\right)$ and carbonyl compounds $\left(\mathrm{C}=\mathrm{O}: 1720 \mathrm{~cm}^{-1}\right)$ were compared for each sample, as they were normalized for the intensities of the amide I $\left(1650 \mathrm{~cm}^{-1}\right)^{14)}$. This calibration provides relative comparison of the amounts of cysteic acid deposited onto the films.

\section{Results and Discussion}

\subsection{Quantification of carbonylated proteins in keratin film induced by artificial sunlight irradiation}

Recently, we found the formation of carbonylated protein in natural black hair by daily sunlight exposure and established a visualization method to detect the photo-modification ${ }^{9}$. However, this method was unsuitable for hair that had been bleached because of the uniformity of hair samples created by this treatment. The characteristics of hair are different among individual persons; furthermore, even the characteristics in one strand of hair are actually heterogeneous from hair root to tip. Thus, we applied the films consisting of hair proteins in place of hair samples to examine more accurate data for the photo-modification.

Fig. -1 shows the photographs of 5 kinds of keratin films obtained by the combination of casting methods and two kinds of hair protein solutions. The translucent films were obtained from the combination of the post-cast method and hair protein solution containing DTT, and other films were white and opaque. These films were irradiated with artificial sunlight and the reaction with 5-FTSC was observed with a fluorescent microscopy. The fluorescence intensity of carbonylated proteins reacting with 5-FTSC increased in proportion to irradiation time and the values of coefficient of correlation were calculated in Table -1 . The detection capabilities of time-dependent photo-modification varied among the different procedures used in the film preparation. The films prepared by the pre-cast method and Shindai solution containing DTT were generally regarded as showing the best detection capability among the five kinds of films.

Fig. -2 A shows the reactivity with 5-FTSC observed by a fluorescent microscope. When the pre-cast keratin films were irradiated at $55 \mathrm{~J} / \mathrm{cm}^{2}$, a time-dependent increase in the fluorescent intensity was found in these films, whereas the intensity was little changed in the shielded films. The average fluorescence intensity was calculated by image analysis (Fig.-2B). The value of the correlation coefficient was 0.97 , indicating that the continuous formation of carbonylated proteins is linked to the irradiation time. Irradiation for $10 \mathrm{~min}$ was enough to prove this significant point. Therefore, the pre-cast keratin film was confirmed to be suitable for detecting the photo-alteration and was used in the following experiments.

\subsection{Identification of carbonylated proteins in the keratin film by immunoblot analysis}

We examined the presence of carbonylated proteins in the keratin films by immunoblot analysis (Fig. -3 ). When proteins were extracted at $5 \mathrm{mg} / \mathrm{ml}$ from the keratin films irradiated for $0,60,120$, and $240 \mathrm{~min}$, the concentrations 


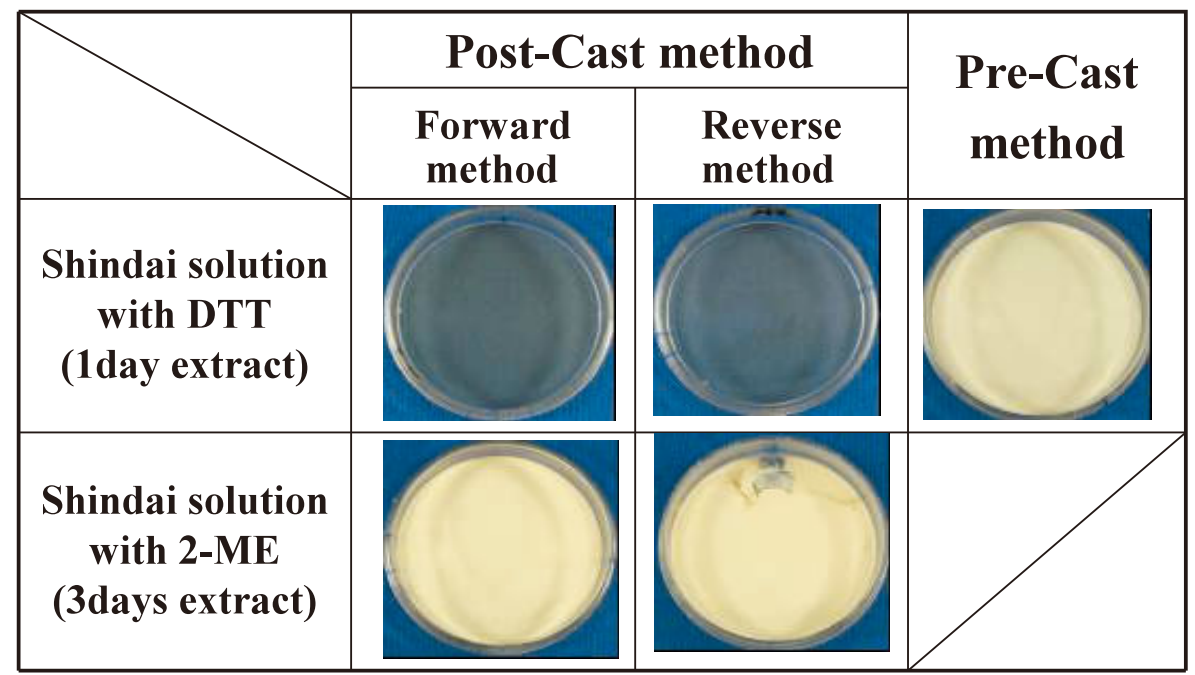

Fig.-1 Photographs of the human hair protein films.

A)

\begin{tabular}{|c|c|c|c|c|c|}
\hline & $10 \mathrm{~min}$ & $30 \mathrm{~min}$ & $60 \mathrm{~min}$ & $120 \mathrm{~min}$ & $240 \mathrm{~min}$ \\
\hline $\begin{array}{l}\text { Irradiated } \\
\text { area }\end{array}$ & & & & & \\
\hline $\begin{array}{l}\text { Non- } \\
\text { irradiated } \\
\text { area }\end{array}$ & & & & & \\
\hline
\end{tabular}

B)

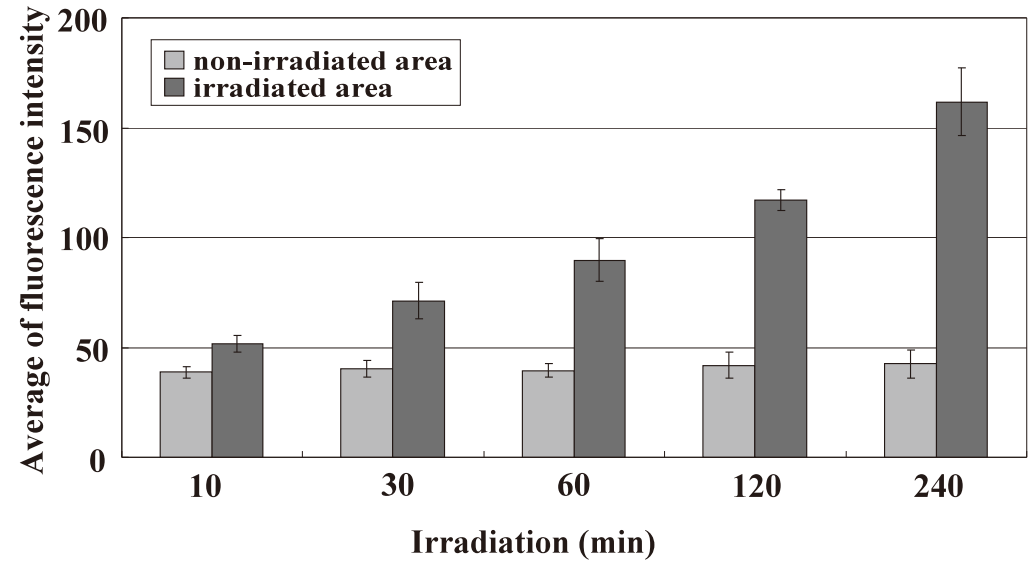

Fig.-2 Fluorescence images and intensity of the keratin films reacting with 5-FTSC after artificial sunlight irradiation.

A) The keratin films with or without shielding filter were irradiated for 0-240 min by an artificial sunlight. After reaction with 5-FTSC, the films were observed by fluorescent microscopy.

B) Average of fluorescence intensity of Fig. - 2A was obtained by image analysis. 
Table-1 Correlation coefficient of the hair protein films between the fluorescence intensity and irradiation time.

\begin{tabular}{|c|c|c|c|c|}
\hline Reducing agent & \multicolumn{2}{|c|}{ Casting method } & $\begin{array}{c}\text { Denaturant } \\
\text { solution }\end{array}$ & $\begin{array}{c}\text { Correlation } \\
\text { coefficient }\end{array}$ \\
\hline \multirow{3}{*}{$\begin{array}{l}\text { Shindai solution } \\
\text { with DTT }\end{array}$} & \multirow{2}{*}{$\begin{array}{l}\text { Post-cast } \\
\text { method }\end{array}$} & $\begin{array}{l}\text { Forward } \\
\text { method }\end{array}$ & \multirow{2}{*}{$\begin{array}{l}\text { Acetate buffer } \\
\quad(\mathrm{pH} \mathrm{4.0)}\end{array}$} & 0.65 \\
\hline & & $\begin{array}{l}\text { Reverse } \\
\text { method }\end{array}$ & & 0.73 \\
\hline & Pre-cast $\mathrm{m}$ & & Acetic acid & 0.97 \\
\hline \multirow{2}{*}{$\begin{array}{l}\text { Shindai solution } \\
\text { with } 2-\mathrm{ME}\end{array}$} & \multirow{2}{*}{$\begin{array}{l}\text { Post-cast } \\
\text { method }\end{array}$} & $\begin{array}{l}\text { Forward } \\
\text { method }\end{array}$ & \multirow{2}{*}{$\begin{array}{l}\text { Acetate buffer } \\
\quad(\mathrm{pH} 4.0)\end{array}$} & 0.90 \\
\hline & & $\begin{array}{l}\text { Reverse } \\
\text { method }\end{array}$ & & 0.62 \\
\hline
\end{tabular}

of recovered proteins were 4.1, 3.9, 3.7, and $3.2 \mathrm{mg} / \mathrm{ml}$, respectively. This indicated that the proteins in the keratin film like in hair samples are liable to aggregate by artificial sunlight irradiation ${ }^{9)}$. Electrophoresis showed little difference among the solubilized proteins which consisted of type I and type II keratins, KAPs, and high-molecular weight proteins (HMPs) (Fig.-3). A considerable amount of proteins from non-irradiated film could cross-react with the antibody, indicating that carbonylated proteins were originally included. When the films were irradiated with the artificial sunlight, the higher cross-reactivity was found in type I keratin, KAPs, and HMPs, indicating that non-specific oxidative reactions occurred on the film proteins. However, the sensitivity was low compared with the fluorescence microscopic observations using 5-FTSC as shown in Fig. $-2 \mathrm{~B}$.

\subsection{Detection of oxidative amino acids by FT-IR measurement}

Dubief et al. reported a case study of the FT-IR in which sunlight-exposed (several months, $80000 \mathrm{~J} / \mathrm{cm}^{2}$ ) human hair absorbed 1.54 times more of the absorption bands originated from both cysteic acid $\left(\mathrm{RSO}_{3} \mathrm{H}: 1041 \mathrm{~cm}^{-1}\right)$ and carbonyl compounds $\left(\mathrm{C}=\mathrm{O}: 1720 \mathrm{~cm}^{-1}\right)$ compared to non-irradiated hair $^{14)}$. In order to evaluate the feasibility of our proposed keratin film method, we examined the photo-induced structural alteration of proteins and amino acids by using FT-IR (Fig.-4). We prepared three keratin films of the same kind, and exposed them under artificial sunlight in different duration (non irradiation, 1 and $4 \mathrm{~h}$ irradiation). Then the IR-spectrum was measured for each keratin film. The result showed the increase of the $1041 \mathrm{~cm}^{-1}$ band for the keratin film of $4 \mathrm{~h}$ exposure. This indicated that cysteic acid increased in keratin film after $4 \mathrm{~h}$ irradiation. Yet, the absorption band around $1720 \mathrm{~cm}^{-1}$, which indicates the carbonyl compounds formation, was not detected. We conducted a preliminary experiment that examined human hair under the same experimental conditions; however, we could not detect the IR band related to either cysteic acid or carbonyl compounds (data not shown). In our previous study, photo-induced carbonylated proteins were localized in the outer structure of the hair (cuticle) $)^{9)}$. Therefore the fluorescent observation of the surface on the keratin films or the hair fiber is more effective in detecting the photo-induced carbonylated proteins. However, the FTIR experiments using the whole hair fiber may be less effective in detecting photo-induced modification ${ }^{9)}$, because single hair fiber is mainly occupied by the pigmented cortex. Our results implied that the FT-IR is effective to detect cysteic acid formation on keratin films after photo exposure, but hardly suitable for evaluation of the carbonyl compound formation.

\subsection{Effect of wavelength interval on the formation of carbonylated proteins in the keratin film}

UV exposure is generally responsible for skin aging. The negative effects of UVB on the skin are principally due to sunburn and chromosomal damage, and UVA exposure produces suntan and oxidative stress caused by reactive oxygen species ${ }^{15}$. On the other hand, prolonged exposure of hair to UVA and UVB is considered to induce modification in the proteins, lipids, and melanin granules ${ }^{16)}$.

In this investigation, the hair keratin film was irradiated with light of wide wavelengths from $300 \mathrm{~nm}$ (UV region) to $780 \mathrm{~nm}$ (VIS). To assess the influence of UVA, UVB, and VIS on the formation of carbonylated proteins, the keratin films were exposed with two different optical filters. The characteristics and the spectral power distribution of the filters were shown in Fig. -5 and Table -2 , respectively. The UVB filter exhibited $98 \%$ cutoff in the irradiance of the UVB region and the UVA + UVB filter could shield more than $99 \%$ of irradiance in the UVA and UVB regions. After irradiation of the keratin films with or without these filters for $60 \mathrm{~min}$, fluorescent intensities were mea- 


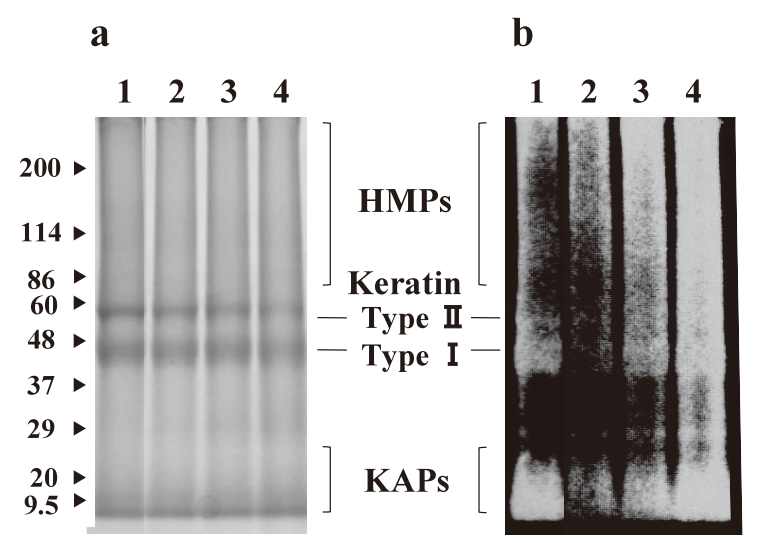

Fig.-3 Identification of oxidative proteins in solubilized samples from the keratin films.

Proteins were solubilized from the keratin films irradiated for $0,60,120$ and 240 min by an artificial sunlight. The samples were subjected to $5-20 \%$ SDS-PAGE and transferred to nitrocellulose membranes. a) Amide black staining. b) Immunostaining with anti-DNP antibody. Lane 1, non-irradiation; lane 2, $60 \mathrm{~min}$ irradiation; lane 3, $120 \mathrm{~min}$ irradiation; lane 4, $240 \mathrm{~min}$ irradiation.

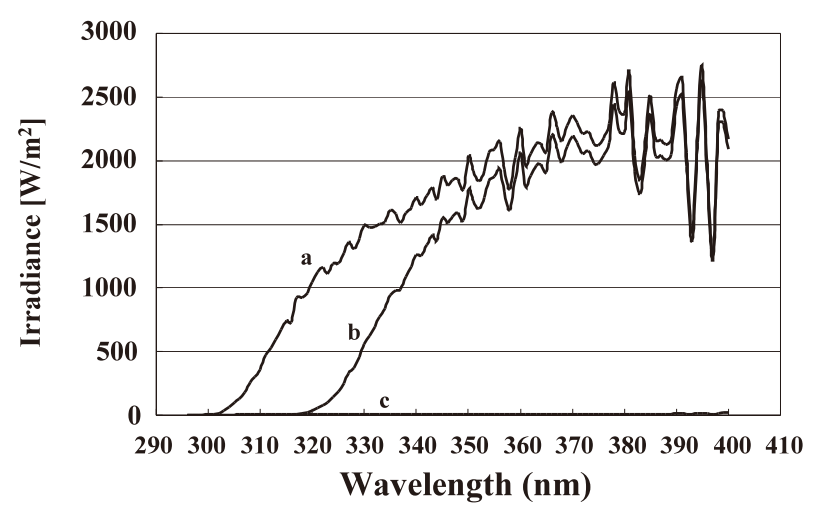

Fig. -5 The spectral distribution of irradiance using solar simulator with/without optical filters. a, UVB + UVA + VIS; b, UVA + VIS; c, VIS.

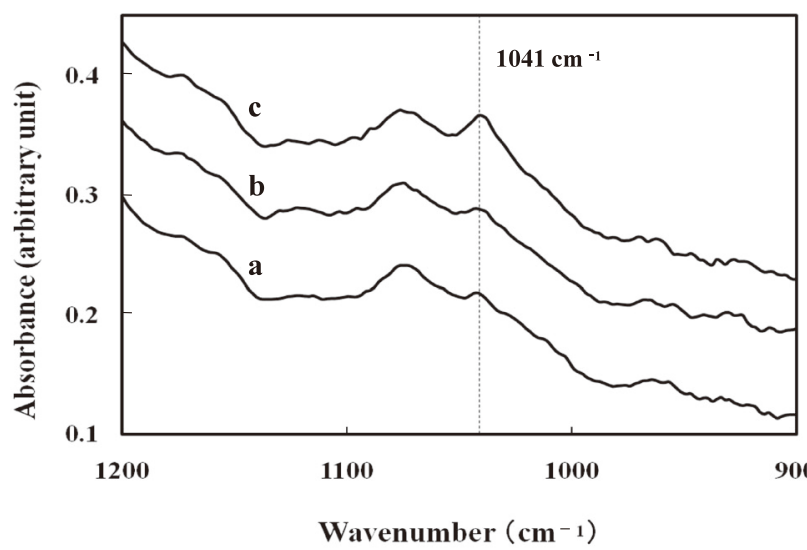

Fig. -4 FT-IR spectra of the keratin films.

a, non-irradiation; b, 60 min irradiation; c, 240 min irradiation.

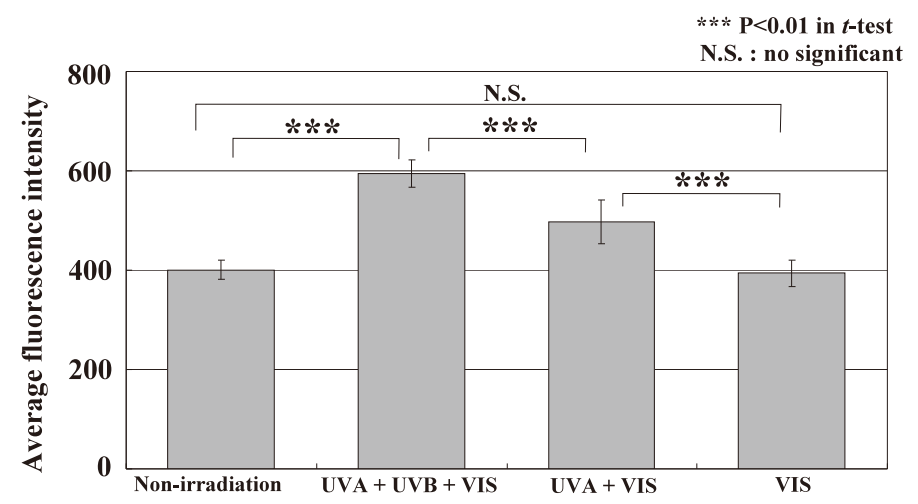

Fig.-6 Effects of UVA, UVB, and VIS on the formation of carbonylated proteins.

The keratin films were irradiated with or without optical filters for $60 \mathrm{~min}$. The average fluorescence intensity was calculated.

Table-2 Artificial sunlight irradiance with or without optical filters.

\begin{tabular}{ccc}
\hline \multirow{2}{*}{ Irradiation } & \multicolumn{2}{c}{ Total irradiance $\left[\mathrm{W} / \mathrm{m}^{2}\right]$} \\
\cline { 2 - 3 } & UV-B $(295-320 \mathrm{~nm})$ & UV-A $(321-400 \mathrm{~nm})$ \\
\hline $\begin{array}{c}\text { Irradiation without } \\
\text { optical filters }\end{array}$ & 9.106 & 155.03 \\
$\begin{array}{c}\text { Irradiation with } \\
\text { UVB cut filter }\end{array}$ & 0.161 & 126.75 \\
$\begin{array}{c}\text { Irradiation with } \\
\text { UVA+B cut filter }\end{array}$ & 0.055 & 0.55 \\
\hline
\end{tabular}


sured (Fig.-6). Compared with the fluorescence intensity without any filter, significant decrease of the intensity was observed when the film was irradiated with the UVB cut filter. Further decrease was found when the UVA and UVB cut filter was used in place of the UVB filter. The value from the films irradiated through the UVA and UVB cut filter was close to that of non-irradiated films. These results indicated that both UVA and UVB promoted the formation of carbonylated proteins under $60 \mathrm{~min}$ irradiation, which was relatively short-term exposure such as in daily life.

In the present study, we developed a novel and sensitive method for quantifying UV-induced modification in the hair proteins, by using the keratin films instead of hair samples. A lot of cosmetic research has been utilizing human hair samples and has been embarrassed as a result, due to the characteristics of hair that has not only individual variances but also different histories of hair damage. Thus, it is difficult to obtain accurate data from hair samples. On the other hand, when human hair keratin film was used, less fluctuant data was obtained because the films were homogeneous. Furthermore, the sensitivity of the film to detect photo-modification was higher compared with hair samples, because the irradiation for $10 \mathrm{~min}$ by artificial sunlight was enough for the film to detect the formation of carbonylated proteins. Interestingly, protein carbonylation was induced by both UVA and UVB. The application of this method could enable us to develop a variety of hair care products for protecting hair from sunlight exposure with shorter intervals of time. Since the keratin films will be applicable to evaluate various kinds of hair damage such as by UV-rays, these lines of investigation are currently in progress.

\section{Acknowledgment}

This research was supported by CLUSTER (the second stage) of Ministry of Education, Culture, Sports Science and Technology, Japan.

\section{References}

1) S. B. Ruetsch, Y. Kamath, H. -D. Weigmann, J. Cosmet. Sci., 51 (2), 103-125 (2000)

2) Z. Shinjo, M. Sadai, A. Nakamura, N. Nishikawa, J. Soc. Cosmet. Chem. Jpn., 28 (1), 66-76 (1994)

3) T. Kawasoe, T. Fujiyama, H. Shimizu, J. Jpn. Cosmet. Sci. Soc., 31 (4), 273-279 (2007)

4) M. Tatsuda, M. Uemura, K. Torii, M. Matsuoka, J. Soc. Cosmet. Chem. Jpn., 21 (1), 43-49 (1987)

5) E. Hoting, M. Zimmermann, J. Soc. Cosmet. Chem., 48 (2), 79-91 (1997)

6) S. Kanetake, K. Tomizawa, H. Iyo, Y. Nakamura, J. Soc. Cosmet. Chem. Jpn., 27 (3), 424-431 (1993)

7) E. Hoting, M. Zimmermann, S. Hilterhaus-Bong, J. Soc. Cosmet. Chem., 46 (2), 85-99 (1995)

8) E. Hoting, M. Zimmermann, J. Soc. Cosmet. Chem., 47 (4), 201-211 (1996)

9) T. Kawasoe, T. Watanabe, T. Fujii, J. Jpn. Cosmet. Sci., 34 (4), 287-291 (2010)

10) A. Nakamura, M. Arimoto, K. Takeuchi, T. Fujii, Pharm. Bull., 25 (5), 569-572 (2002)

11) T. Fujii, D. Ogiwara, M. Arimoto, Biol. Pharm. Bull., 27 (1), 89-93 (2004)

12) M. M. Bradford, Anal. Biochem., 72, 248-254 (1975)

13) U. K. Laemmli, Nature (London), 227, 680-685 (1970)

14) C. Dubief, Cosmet. Toilet., 107 (10), 95-102 (1992)

15) G. Wakefield, J. Stott, A. Duggan, Cosmet. Toilet., 122 (2), 57-62 (2007)

16) V. Signori, J. Cosmet. Sci., 55 (1), 95-113 (2004) 


\title{
ケラチンフィルムを用いた毛髪タンパク質の 光劣化に関する新規定量法の開発*
}

\author{
川副智行吕, 渡辺智子**, 藤井敏弘*** \\ 株式会社資生堂 リサーチセンター** \\ 信州大学 繊維学部 応用生物学系***
}

以前のわれわれの研究で, フルオレセイン 5 チオセミカルバジド（5-FTSC）亡蛍光顕微鏡を用い た光曝露による毛髪構成タンパク質の力ルボ二ル化を検出する手法を開発した。本研究では, ケラチ ンとケラチン関連タンパク質（KAPs）からなる毛髪ケラチンフィルムを毛髪の代わりに用いて実験 を実施した。数種のケラチンフィルムを用いて光照射による蛍光強度を確認した結果, プレーキャス ト法で作製したフィルムが, 最もカルボニル化タンパク質の生成を検出できることがわかった。この フィルムでは, 光曝露時間に比例した蛍光強度の増加が確認され, 高い相関係数 $\left(R^{2}=0.97\right)$ が得 られた。また, わずか 10 分の光曝露照射でも差を検出可能で, 毛髪に比べ約 6 倍の感度を示す結果 となった。さらに, UVA とUVB 曝露による影響も感度よく検出可能であった。イムノブロット解 析では, 120 分の光曝露でタンパク質の酸化が確認されたが, 蛍光顕微鏡による結果に比べて短時間 の光照射では変化を確認できなかった。また, ケラチンフィルムを用いたFTIRによる分析では, 240 分の光懪露によるシステイン酸の生成が検出可能であったが, カルボ二ルの検出はできなかった。 